\title{
MARKET RESEARCHES
}

MEREZHKO N., ZOLOTAROVA O.

The impact of the COVID-19 pandemic

on the world market of elite goods . .4

ANDRIIEVSKA L., HLUSHKOVA T., KOLOMIETS T.

World smartphone market.

\section{CYBERSECURITY IN THE INFORMATION SOCIETY}

BILIAVSKA YU., MYKYTENKO N., SHESTAK YA.

Cybersecurity and the information protection

during the COVID-19 pandemic .34

INNOVATIVE MARKETING

PIATNYTSKA G., HRYHORENKO O., TARASIUK M.

Vending trade: typification, benefits and risks

MOLCHANOVA E., KOVTONYUK K.

Mobile telephony in the digital age.

BOVSH L., RASULOVA A., OKHRIMENKO A.

Geographic map of the restaurant's customer environment:

scientific substantiation 76

FINANCIAL SERVICES MARKET

AVANESOVA I.

Financial services market assets in Ukraine .86

IMPROVEMENT OF GOODS PROPERTIES

OSYKA V., KOMAKНА О., КОМАКНА V.

Waterproof paper packaging materials:

comprehensive quality assessment.

BOZHKO T., ZAHRIVAIA I., BOLILA N.

Commodity assessment of female hygiene products 106

RESEARCHES OF FOODSTUFF'S QUALITY

SYDORENKO O., PETROVA O., DONCHEVSKA R.

Biological value of Palaemon adspersus shrimp powder. 